\title{
Do Companies Manipulate CSR Information to Retain Legitimacy?
}

\author{
Halina Waniak-Michalak ${ }^{1}$, Alfreda Sapkauskiene ${ }^{2}$, Sviesa Leitoniene ${ }^{2}$
}

${ }^{1}$ University of Lodz

Matejki 22/26 st. Lodz, Poland

E-mail.hwaniak@uni.lodz.pl

${ }^{2}$ Kaunas University of Technology

K. Donelaicio st. 73, LT-44029, Kaunas, Lithuania

E-mail.alfreda.sapkauskiene@ktu.lt,sviesa.leitoniene@ktu.lt

cross $^{\text {ref }}$ http://dx.doi.org/10.5755/j01.ee.29.3.18946

Corporations' involvement in activities that are socially responsible, with respect for workers' rights and ethically principled, brings tangible benefits to the enterprise. These CSR benefits include an increase in stakeholders' assessment of the corporation with a boost in perceived trustworthiness. Companies, however, may treat sustainability reports as a tool to legitimize their actions. In order to achieve the desired results from CSR activities, companies disclose only selected information to customers, employees and/or owners. The aim of this paper is to answer the question of whether companies change measures in subsequent CSR reports to avoid revealing unfavorable information in sustainability reports. We analyzed 116 reports of corporations from different countries: Poland, Czech Republic, Hungary, Slovakia, Lithuania, Estonia, Ukraine and Latvia. We used the reports from the website: http://database.globalreporting.org/ For every company we used two newest reports for two consecutive years in the period 2010-2016. We used t-test to verify the hypothesis that companies remove and add the same number of CSR measures in subsequent reports and that corporations from controversial industries change disclosed information to higher extent than companies from other industries. We stated, that companies replace one measure with the new one to keep the impression of the same level of disclosure and to maintain or increase the level of legitimacy. Research showed that companies change the number and type of disclosed measures and they don't explain reasons of the changes made in the reports, which may indicate a desire to green the organization by presenting only positive information. However, we can't confirm that there is a significant difference in changes of CSR measures revealed between companies from controversial and non-controversial industries. The paper fills a research gap in the research on the reliability of CSR disclosure. It concentrates on the motives and the range of measures unveiled in the sustainability reports to legitimize a company's activity.

Keywords: Indicators; Corporate Social Responsibility; Global Reporting Initiative; Stakeholders; Controversial Industries.

\section{Introduction}

Success resulting from business activity depends largely on the level of the development of society, its wealth, the level of "happiness" and knowledge. Corporate social responsibility is a "philosophy of doing business", which is about building and developing long-lasting relationships with all stakeholders (Theodoulidis et al., 2017). Social responsibility is the obligation of an organization to strengthen and protect the environment in which it operates (Valackiene \& Miceviciene, 2011), with the aim of building and implementing the correct management strategy leading to an increase in the competitiveness of the company, as well as building its image and reputation (Virvilaite \& Daubaraite, 2011). In addition, the implementation of the CSR concept brings the added strategic advantage of building a competitive advantage. CSR activities should take place through the creation of conditions for partnership cooperation with customers, suppliers, employees and other stakeholders. One of the objectives of CSR activities is to build attractive conditions for socio-economic development at the local, regional or even global market level.
CSR strategy should be based on gaining and delivering sustainable value not only for shareholders, but also for other stakeholders (Theodoulidis et al., 2017). Achieving a balance between maximizing profits and social well-being requires enterprises to engage in those socially responsible actions that are also favorable for the company itself (Wang \& Chen, 2017). The aim of CSR is therefore to obtain benefits like an improvement of a company's image (Du et $a l ., 2010$ ). The benefits may be substantial (direct and easily measurable) like an increase of products sold or willingness of customers to pay higher price for products or services. A company that involves in CSR activity may also seek for indirect benefits, usually long-term, like the ability to find better employees in the future or have a better access to financing.

CSR is a process that should enable the company to fulfill stakeholders' expectations (Segui-Alcaraz, 2012), while monitoring the impact of this activity on the company's competitiveness and market value (Juscius \& Jonikas, 2013; Daszynska-Zygadlo et al., 2016)). The CSR measures can be wide ranging, taking into consideration the diversity of the expectations of the various stakeholders: shareholders, suppliers, employees, government institutions, 
social organizations, society at a local and regional level clients and creditors.

CSR activities, as mentioned earlier, can lead to an improvement in the financial situation for the business. These economic benefits may result from meeting the expectations of stakeholders, who then reward the socially-responsible company with greater trust. Consumers may then offer greater loyalty and buy greater quantities of products, while investors may be willing to invest their funds in the company and employees work more efficiently because of the increase in job satisfaction (Barakat et al., 2016).

The problem is that assessment of the efficiency of corporate social responsibility is difficult (Vveinhardt \& Andriukaitiene, 2014) due to the fact that the benefits of CSR are usually multidimensional (Chatzoglou et al., 2017). Moreover, CSR activities are treated as charitable, supplementary or just as an element of public relations. Therefore, it is extremely difficult to distinguish the consequences of socially responsible actions from others.

According to Morioka and Carvalho (2016), the literature presents several frameworks for measuring CSR. These can be divided into three categories. The first category classifies CSR indicators encompassed by research that generally focus on GRI indicators which are based on the triple bottom line pillars. The second category suggests a sequential process measurement system of CSR performance. The third category focuses on cause and effect aspects for the CSR performance measurement system. The latter two research areas are directed towards the company's internal CSR assessment. Meanwhile, the first focuses on CSR measurement indicators that are presented to external stakeholders.

Several approaches have merged to help companies face this challenge: performance indices - Dow Jones Sustainability Index (2008), Global Reporting Initiative (GRI, 2006), the United Nations Global Compact (UNGC, 2013) more for external stakeholders and international standards guidelines, and Social Accountability (SA) 8000 and ISO 14000 and 26000 - more for internal CSR measurement. However, these approaches have been criticized as being merely recommendations, superficial rather than effective (Morioka \& Carvalho, 2016). Companies are, therefore, free to understand, to use and to disclose the CSR measures they wish to. Moreover, according to the legitimacy theory, firms from controversial sectors employ CSR reporting with the aim of neutralizing the direct and indirect effects of litigation proceedings which threaten to deteriorate the already adverse context within which they operate. For these reasons, one central point of criticism is the selectivity in CSR reporting concerning what measures to report on. This hampers comparability and transparency (Einwiller et al., 2016). Comparability is important to most users of CSR reports who are interested in the CSR performance of not just one company (Einwiller at al., 2016). Numerous studies indicate that CSR disclosure differs across industry sectors (Cho et al., 2015), which leads to the question of why CSR disclosure differs across different companies in the same sector, and why CSR disclosure may differ year on year for the same company.

With this in mind, the aim of this paper is to answer the question of whether companies change measures in subsequent CSR reports to avoid revealing unfavorable information in sustainability reports.
The novelty of the paper is an investigation if companies change measures published in CSR reports in order to maintain legitimacy.

The following sections of the paper are organized as follows: In the next section we discuss the difficulty of measuring CSR activity and the types of CSR measures that can be used by companies to show their achievements in CSR in the light of legitimization theory. In the third section, we conduct a literature research on the greening of information by companies from controversial industries. Finally, we present a methodology of the research and our results.

\section{CSR Measurement in the Light of Legitimization Theory}

A necessary condition in order to achieve benefits from CSR activities is the continuous development and improvement of those competences that enhance effective cooperation with stakeholders, as well as measurement and analysis of their expectations. Society and shareholders have the right to receive the information concerning the results of CSR, especially if they bear the burden of some of those costs (Hetze, 2016).

Determination of the list of activities that should be measured, however, can be difficult, and depends on the country, social needs, involved individuals and institutions, as well as the duration (Sethi, 1975). Direct benefits and (long-term) results associated with the implementation of CSR may be considered from only the company's point of view, or as benefits for both society and the company.

The relationship between a company's involvement in socially responsible activities and its financial performance is difficult to determine (Brammer \& Millington 2008; Khan et al., 2015). Certain researchers question the positive impact of money spent on the implementation of CSR on financial indicators (Margolis \& Walsh 2001; Dimson et al., 2014). In general, researchers state that CSR activities have a positive impact on the financial results of a corporation, directly or indirectly (e.g. the dependence of the size of any donation to the number of products sold) in the long or short term (Borgers et al., 2013; Eccles et al., 2014; Lee \& Park, 2016). Despite the majority of studies showing a positive correlation between CSR activities and financial performance of operators, there are also those that reveal the reverse relationship (Peloza, 2009; Di Giuli \& Kostovetsky, 2014).

Although financial ratios are the most frequently used measures of CSR performance, these do not always reflect the effects of actions in the short term. Most CSR investments deliver long-term results and can positively influence the financial results of companies many years after the end of the project, e.g. investments in schools, or local infrastructure. Only particular CSR activities can have a positive impact on corporate financial indicators in the short term, e.g. investment in energy-saving infrastructure (Peloza, 2009).

Lulewicz-Sas (2014) indicated that the majority of companies conduct either regular or irregular testing of the effects of the implementation of CSR activities. The most frequently used tools are surveys, direct meetings and informal communication. However, it is impossible to know the methods of CSR measurement used since each corporation uses its own methodology, hampering the comparison of results between companies. The research also 
indicates that some companies do not measure their achievements in the CSR area. Thus, the question arises: what is the credibility and the scope of information presented in the reports of the corporation, if CSR activities are not measured? The quality of information on CSR activities can be affected by reporting standards and their application (Global Reporting Initiative - GRI) (Dagiliene et al., 2014). Given that GRI standards are still not mandatory, and since CSR reports do not have to be audited, corporations are free to understand and to use various CSR measures.

Enterprises deciding to assess the results of CSR may use their own measures or use those according to GRI guidelines (Global Reporting Initiative). Gjolberg (2009), shows that some companies may have difficulties in obtaining relevant data (Douvis et al., 2015), especially if their accounting system does not allow for it. Gathering the information can be time-consuming and still may not meet the information needs of stakeholders. The problem raised by Morimoto et al. (2005): the verification of data could be solved by audits of CSR reports, although the cost of such an audit may outweigh the benefits.

Another problem is the flexibility in the selection of indicators and the methods of measurement, with the result that it is more difficult to compare the outcome of CSR activity across different companies. GRI reporting standards partially solve this problem, however, companies can freely choose from and interpret the measures suggested by GRI. Some companies present hard data, some of them present a description of the situation.

An important issue is the choice of measures which can present the company in a good light. This may cause the situation where minor issues are described in the CSR reports, and crucial ones are side-stepped due to the high level of controversy. Companies try, according to the legitimacy theory, to show their usefulness for society, putting emphasis on achievements and avoiding any discussion of failures.

The legitimacy theory emanates from the idea that in order for a company to succeed, it should act in accordance with the limits and norms that society considers socially responsible (O'Donovan, 2002). Therefore, the legitimacy theory is based on a "social contract" between the company and the society in which it operates (Deegan, Underman, 2011). This "social contract" includes society's expectations about how a company should operate. The legitimacy of a company depends on maintaining mutual relations with its stakeholders, as the company has obligations not only to its shareholders, but also moral obligations for its many stakeholders (Maignan \& Ralston, 2002). Companies try to justify their actions by submitting CSR reports in order to gain public support and thus ensure their continued existence. This is especially important for companies operating in controversial industries (Grougiou et al., 2016). By initiating disclosure of CSR, the companies from controversial industries create a defensive mechanism that can mitigate the negative impact of their activities and reduce social dissatisfaction (Vergner, 2012).

It should be noted that the legitimization theory is most suitable for companies working in developed countries, in which the annual report is considered to be the main way in which such companies provide CSR information for society (Omran \& El-Galfy, 2014). According to Omran and
Ramdhony (2015), for businesses operating in developing countries stakeholder theory seems to be the more suitable. In developing countries companies can manage their stakeholders and the pressure to comply with existing legislation is lower compared to developed countries.

\section{The Measurement of CSR Activity in Controversial Industries and the Greening of Information}

Controversial industries include those economic sectors whose products, services or concepts provoke disgust, indignation, fear, even violating the rules of decency and morality (Cai et al., 2012). Among these controversial companies, we can distinguish companies operating in industries such as tobacco, alcohol, gambling, adult entertainment, arms production, as well as in industries whose activities continuously, directly or indirectly, are harmful to health, the environment or cause ethical dilemmas, e.g. petrochemical industry, biotechnology, nuclear, coal and other mineral resources. The products of these industries lead to either addiction or significant social problems, costing billions of dollars.

Campbell, Craven, Shrives (2003), in turn, have identified these companies as either "sinful" or those whose primary products are perceived negatively. They discussed whether businesses whose activities are particularly harmful to society, such as casinos or cigarette manufacturers, can present a positive impact on society. They considered that such companies will take actions to minimize any negative public perception, in an attempt to prove that they are not "so bad". Campbell, Craven, Shrives (2003) also formulated two hypotheses:

1) companies considered more "sinful" will reveal more information about CSR than "lawful" enterprises;

2) firms with similar levels of "sins" show similar levels of disclosure on sustainable development.

In order to verify these hypotheses, they compared the disclosure of information on sustainable development from 5 companies belonging to the $\mathrm{FTSE}^{1}$, from 3 different sectors: retail, alcoholic beverages and tobacco. The results of the study did not confirm the hypothesis of the authors. It concluded that the tobacco company, considered the most "sinful", presented the least information on sustainable development. Waniak-Michalak and Michalak (2016) also stated that companies from sinful industries disclose the same or even less information than other companies to avoid attracting attention to their charitable donations opinion if their managers have something to hide.

Other researchers also indicate that certain actions taken by companies are an attempt to "green" the company's image (called "green wash") - and that reports of sustainability have more the character of public relations information to improve the companies' image in the eyes of society than the character of the actual environmental impact and achievements in this area (Habek \& Wolniak, 2015). Such reports are not very detailed, containing only limited measures. At the same time, they are full of vague, unsupported statements indicating the positive effects of the

\footnotetext{
${ }^{1}$ Financial Times Stock Exchange 100 Index, also called the FTSE 100 Index
} 
company's activity on the environment and society, wordy but with few concrete measures.

\section{Data and methodology}

We analysed GRI reports from companies operating in Post-Communist Europe: the Czech Republic, Hungary, Slovakia, Poland, Estonia, Lithuania, Latvia, Ukraine. Companies from other countries were not included because of the different levels of civil society development in PostCommunist European countries than in Western European countries (Michalak, Waniak-Michalak, 2016).

In our research, we used the GRI reports of 96 companies operating in Poland, 11 companies from Slovakia, 40 companies from the Czech Republic, 82 from Hungary, 2 from Lithuania, 4 from Estonia, 21 from Ukraine and 9 companies from Latvia. Reports of all companies were taken from the sustainability database website: http://database.globalreporting.org/ For every company we used two newest reports for two consecutive years in the period 2010-2016. If the company prepared only one report in the period, we excluded the company from the sample.

Among the reports of these companies we chose reports prepared according to GRI standards for two subsequent years. Therefore, we analyzed reports of 33 Polish corporations (66 reports), 3 from the Czech Republic (6 reports), 14 from Hungary (28 reports), 2 from Slovakia (4 reports), 1 from Lithuania (2 reports), 1 from Estonia ( 2 reports), 3 from Ukraine (6 reports) and 1 from Latvia ( 2 reports). Companies from three sectors provided the largest share in the sample: financial (28\%), energy industry $(19 \%)$ and food and beverage $(16 \%)$.

In the first stage of the study the collected information on the type of indicators (measures) used by the selected companies was compared and standardized. Standardization was the task in which we assigned the same numbers to measures according to the relationship shown in the Table 1 and 2, for example LA4 according to
G4 was marked in our analysis as LA5 according to G3.1, so we didn't recognize any change.

Since 2000, when the first CSR reporting guidelines were issued by GRI, (an organization created in 1997 by two non-governmental organizations: Coalition for Environmentally Responsible Economies (CERES) and the Tellus Institute with the support of The United Nations Environment Programme (UNEP)) a few versions of CSR reporting have been created. Currently, G4 is the valid version, including 91 detailed indicators in the following areas:

- economic (9 measures)

- protection of the environment (34 measures)

- employment politics (16 measures).

- civil rights (12 measures)

- social impact (11 measures)

- product responsibility (9 measures).

Measures can be used to assess the resources used to carry out CSR activities or the results of this activity. In many cases, because this information is the easiest to obtain, companies assess inputs without determining the results, which could result in an increase in the operating costs of CSR while the results would not necessarily be considered reliable.

Comparing CSR achievements in companies' reports can be difficult due to the structure of the information required by GRI as well as the irregular preparation of reports by companies. The newest version of GRI standards, G4, in comparison with G3.1, has changed greatly. Most of the changes concern the definition of the measure and changes numeration of the measures. Fewer changes relate to the removal or creation of measures. Not all areas were affected equally. Most removed and new measures (in percentages) were in employment. The smallest changes affected the area of product responsibility. A detailed analysis of the changes in GRI standards is presented in Tables 1 and 2 .

Table 1

Changes* of Measures across the Two Different GRI: G3.1 and G4 in Two Areas: Protection of the Environment and Employment Politics in Comparison with G3

\begin{tabular}{|c|c|c|c|c|c|}
\hline G3 & G3.1 & G4 & G32 & G3.1 & G4 \\
\hline EN1 & No change & No change & LA1 & No change & Deleted \\
\hline EN2 & No change & No change & LA2 & Change of name & $=L A 1$ \\
\hline EN3 & No change & No change & LA3 & Change of name & Deleted \\
\hline EN4 & No change & No change & LA4 & Change of name & Deleted \\
\hline EN5 & No change & =EN6 & LA5 & No change & $=L A 4$ \\
\hline EN6 & No change & $=\mathrm{EN} 7$ & LA6 & No change & $=L A 5$ \\
\hline EN7 & No change & $=$ EN7 & LA7 & Change of name & $=L A 6$ \\
\hline EN8 & No change & No change & LA8 & No change & deleted \\
\hline EN9 & No change & No change & LA9 & No change & $=L A 8$ \\
\hline EN10 & No change & No change & LA10 & No change & $=L A 9$ \\
\hline EN11 & No change & No change & LA11 & No change & $=L A 10$ \\
\hline EN12 & No change & No change & LA12 & No change & $=L A 11$ \\
\hline EN13 & No change & No change & LA13 & No change & $=L A 12$ \\
\hline EN14 & No change & deleted & LA14 & No change & $=L A 13$ \\
\hline EN15 & No change & $=\mathrm{EN} 14$ & & & \\
\hline EN16 & No change & $=$ EN15 & & & \\
\hline EN17 & No change & No change & & & \\
\hline EN18 & No change & $=$ EN19 & & & \\
\hline EN19 & No change & $=\mathrm{EN} 20$ & & & \\
\hline EN20 & No change & $=\mathrm{EN} 21$ & & & \\
\hline EN21 & No change & $=\mathrm{EN} 22$ & & & \\
\hline
\end{tabular}




\begin{tabular}{|c|c|c|c|c|c|}
\hline G3 & G3.1 & G4 & G32 & G3.1 & G4 \\
\hline EN22 & No change & $=\mathrm{EN} 23$ & & & \\
\hline EN23 & No change & $=\mathrm{EN} 24$ & & & \\
\hline EN24 & No change & $=\mathrm{EN} 25$ & & & \\
\hline EN25 & No change & $=\mathrm{EN} 26$ & & & \\
\hline EN26 & No change & $=\mathrm{EN} 27$ & & & \\
\hline EN27 & No change & $=\mathrm{EN} 28$ & & & \\
\hline EN28 & No change & $=\mathrm{EN} 29$ & & & \\
\hline EN29 & No change & $=\mathrm{EN} 30$ & & & \\
\hline EN30 & No change & $=\mathrm{EN} 31$ & & & \\
\hline
\end{tabular}

Source: Own elaboration

*change in comparison with previous standards of reporting

Table 2

Changes* of Measures Across the Two Different GRI: G3.1 and G4 in Three Areas: Civil Rights, Social Impact and Products Responsibility in Comparison with G3

\begin{tabular}{|c|c|c|c|c|c|c|c|c|}
\hline G3 & G3.1 & G4 & G3 & G3.1 & G4 & G3 & G3.1 & G4 \\
\hline HR1 & Change of name & $\begin{array}{c}\text { Change of } \\
\text { name }\end{array}$ & SO1 & No change & No change & PR1 & No change & No change \\
\hline HR2 & Change of name & $=\mathrm{HR} 10$ & SO2 & No change & $=\mathrm{SO} 3$ & PR2 & No change & No change \\
\hline HR3 & No change & $=\mathrm{HR} 2$ & SO3 & No change & $=\mathrm{SO} 4$ & PR3 & No change & No change \\
\hline HR4 & No change & $=\mathrm{HR} 3$ & SO4 & No change & $=\mathrm{SO} 5$ & PR4 & No change & No change \\
\hline HR5 & No change & Deleted & SO5 & No change & $=\mathrm{SO} 6$ & PR5 & No change & No change \\
\hline HR6 & Change of name & $=\mathrm{HR} 5$ & SO6 & No change & Deleted & PR6 & No change & deleted \\
\hline HR7 & Change of name & $=\mathrm{HR} 6$ & SO7 & No change & No change & PR7 & No change & No change \\
\hline HR8 & No change & $=\mathrm{HR} 7$ & SO8 & No change & No change & PR8 & No change & No change \\
\hline HR9 & No change & $=\mathrm{HR} 8$ & & & & PR9 & No change & No change \\
\hline
\end{tabular}

Source: Own elaboration.

* Change in comparison with previous standards of reporting.

In the second stage of the study we used statistical analysis in order to verify our hypothesis (formulated on the base of literature research and preliminary analysis). Our first hypothesis H1. Changes of measures used in CSR reports concern the removal of a measure and the addition of a new measure equally was based on the assumption that companies reveal more information on CSR activity if it is going to resonate and garner positive results (Browning et al., 2018). In order to hide negative information but to keep the same level of disclosure, companies may manipulate the information by a replacement of one measure with another measure. In our preliminary analysis we discovered that one company replaced the measure "Total workforce by employment type, employment contract, and region broken down by gender" with "Ratio of basic salary of men to women by employee category". It was done to hide the fact that the company had to decrease its activity and close shops in a particular area, causing an increase of unemployment in the region. Some researchers search for consequences of the manipulation of CSR information if it is discovered by stakeholders. However, Calveras and Ganuza (2015) conclude that companies manipulate the CSR information if it is possible and if the probability of detecting the manipulation is low.

Because controversial companies, according to the literature research (Cai et al., 2012), may perceive the benefits resulting from CSR reporting as greater, they may be more willing to manipulate the disclosed information. Therefore, we expected that the number of changes made in CSR reports in such companies may be higher than in other corporations and formulated the second hypothesis $\mathrm{H} 2$ Corporations from controversial industries change the measures used more than other companies.

\section{The Range of Measures in CSR aActivities - Analysis Results and Discussion}

Preliminary statistics analysis has proved the low range of the number of indicators used. Given the evolution of GRI standards, however, we should expect an increase in the number of measures. Moreover, the t-test did not allow us to reject the null hypothesis of an equal average number of measures used in the subsequent CSR reports of companies in the analyzed periods ( $\mathrm{p}$ value $=0.57$ ). It may mean that companies manipulate the types of measures used (replacing one measure with another) to maintain the level of reporting but to show better results.

Removal of those measures which can present a company in a bad light is evidence of using CSR reports to improve a company's image. Organizations can change the measures used, depending on whether the results fulfil the expectations of stakeholders or not.

In order to verify $\mathrm{H} 1$, t-test was used for dependent groups (the research concerns the same group of companies) (Table 3).

The analysis showed that the company deleted an average of 6 measures and added 7. Although the average number of removed indicators was a little lower than the number of added measures, t-test confirmed that there is not a significant difference between the means $(p=.698)$, hence hypothesis $\mathrm{H} 1$ was confirmed. It means that companies replace CSR measures previously used with other indicators. This practice rise doubts concerning the reliability of the information presented in CSR reports. 
Table 3

Statistics from t-Test for the Hypothesis $\mathrm{H1}$

\begin{tabular}{|l|c|c|c|c|}
\hline & Mean & Number of entities & Standard deviation & Standard error mean \\
\hline Added & 6.09 & 58 & 6,929 & .910 \\
\hline Removed & 5,64 & 58 & 5,742 & .754 \\
\hline
\end{tabular}

Source: Own elaboration in SPSS Statistics 21

The legitimization theory presented in the paper indicated that companies from sinful industries may have higher incentives to manipulate the types of disclosed information on CSR activity. In order to verify hypothesis $\mathrm{H} 2$, that corporations from controversial industries change the measures more than other companies, we used t-test for independent samples.
The t-test did not lead us to accept hypothesis H2. It turned out that the mean of the changes (the number of deleted or added measures and number of measures disclosed in the following years) did not vary significantly for companies from controversial or other industries (Figure 1). The outcomes of the t-test are presented in Table 4.

Table 4

Statistics of the t-Test for the Hypothesis $\mathbf{H 2}$

\begin{tabular}{|l|c|c|c|c|c|}
\hline & Sig. (2-tailed) & Mean Difference & \multicolumn{2}{|c|}{$\begin{array}{c}\text { Std. Error } \\
\text { Difference }\end{array}$} & \multicolumn{2}{|c|}{ 95 \% Confidence Interval of the Difference } \\
\cline { 3 - 5 } & & & 1.650 & Upwer & -2.491 \\
\hline Added & .606 & .858 & 2.094 & -4.095 \\
\hline Removed & .934 & .174 & 3.196 & 4.206 \\
\hline Net change* & .783 & .889 & 4.443 & -5.644 \\
\hline
\end{tabular}

Source: Own elaboration in SPSS Statistics 21

*added measures minus removed measures

Analysis indicated that the measure E4 (Indirect energy consumption by primary energy sources) was removed by the largest number of companies, while measures such as HR8 (Percentage of security personnel trained in the organization's policies or procedures concerning aspects of human rights that are relevant to operations) and EN 25 (Identity, size, protected status, and biodiversity value of water bodies and related habitats significantly affected by the reporting organization's discharges of water and runoff) were removed by all companies that disclosed them in previous reports. The most significant negative changes (removing measures) related to the area of product responsibility (PR) and the least number of deleted measures was in the field of human rights (HR). The company that removed the highest number of measures (31) from the report added only 4 new measures. Five companies did not remove any measure.

If a company removes any measure, the change should be explained in the CSR report, however, the analyzed companies did not present such information. This may indicate that the assumption that companies choose the information presented in sustainability reports to improve their image is true. In some cases, companies stated only the message: "not applicable" or "not reported" or "the company does not disclose such information." According to the requirement of GRI standards, at the point of G4-22 and G4-23 the company should: "Report the effect of any restatements of information provided in previous reports, and the reasons for such restatements." and "Report significant changes from previous reporting periods in the Scope and Aspect Boundaries ".

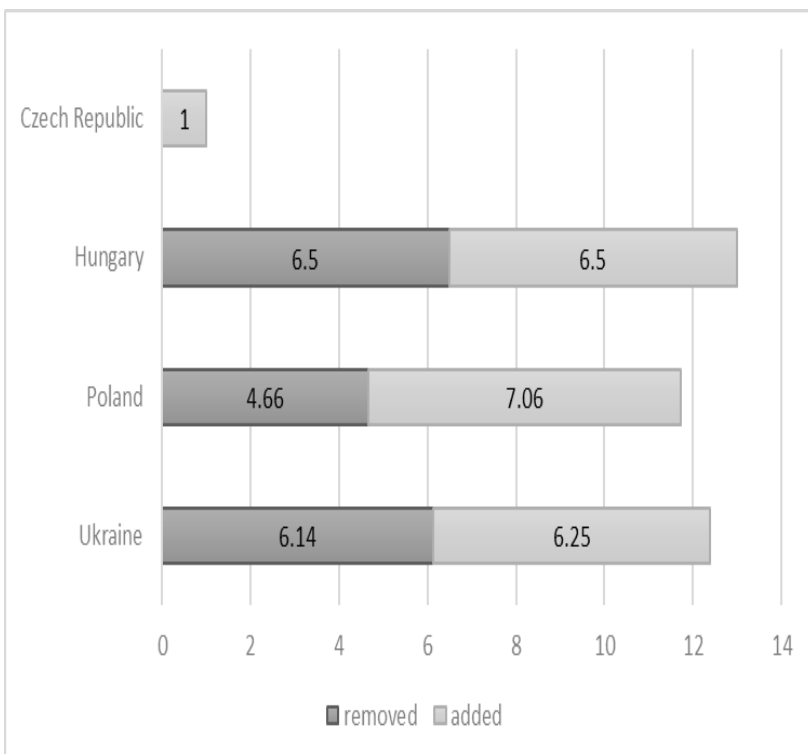

Controversial Industries

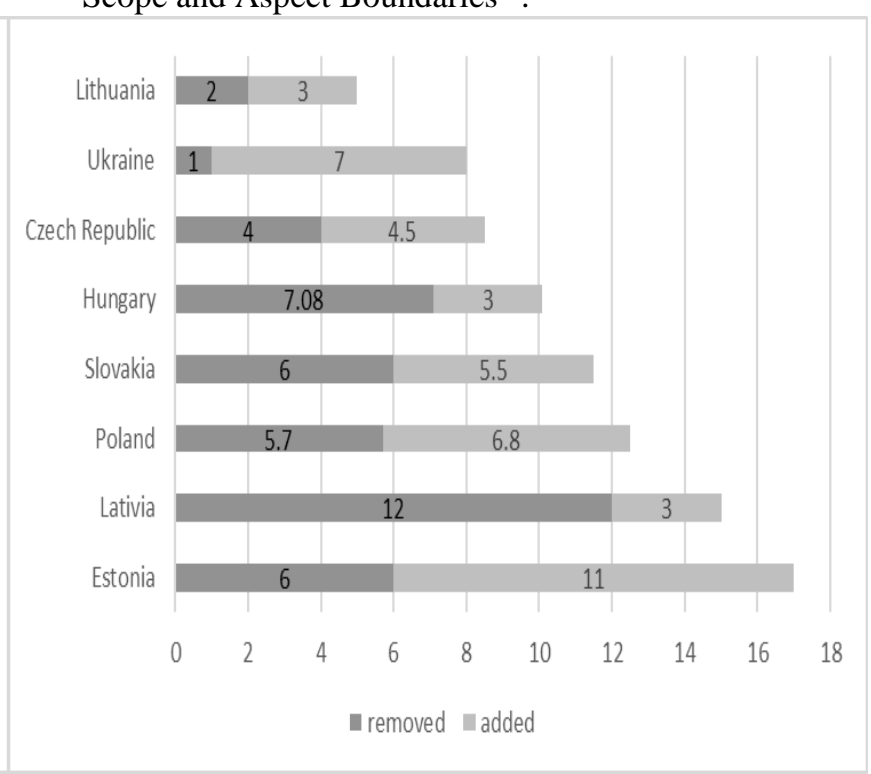

Non-Controversial Industries

Source: Own elaboration

Figure 1. Average Change in CSR Measures in Controversial and Non-Controversial Industries 
Our research shows that companies change CSR indicators presented in CSR reports, however we can't directly draw a conclusion that the companies manipulated the CSR information. There may be different reasons of the fact. The change of CSR measures may result from a change of CSR strategy, access to the information, CSR manager decision. Also, the industry practices influence the disclosure of CSR results. If many companies in the sector disclose the information, the probability of revealing the information in the report of another company grows (Peng et al., 2015). The study of Cheng et al. (2015) underline the importance of strategic relevance of CSR indicators. Then, if the strategy changes the indicators may change too.

However, we may see the symptom of the manipulation not only in a change of indicators, but also in a lack of explanation of the reason of the change. Some companies may be willing to manipulate the level of disclosure to present only positive achievements in the field (Kuo \& Chen, 2013). Avoiding a disclosure of negative information may be a reason of a low level of CSR information comparability and then decrease the usefulness of sustainability reports.

\section{Conclusions}

The aim of this paper was to answer the question whether companies change measures in subsequent CSR reports to avoid revealing unfavorable information in sustainability reports to retain legitimacy. Our research proved that companies change CSR measures presented in CSR reports, however we can't conclude that the companies did it to present themselves in a better light.

Companies preparing CSR reports should present their achievements depending on their measurement capabilities and the requirements of their stakeholders. Corporations are able to choose from the proposed measures in the GRI standards, as well as to apply their own indicators according to their needs. The necessity to ensure the comparability of reports should not only refer to financial statements but also CSR reports, especially now when more and more companies prepare integrated reports. Moreover, former studies prove that investors prefers nonfinancial information that is concise, comprehensive, comparable, and credible (Cohen et al., 2015).

Analysis of the content of CSR reports has shown that companies reveal a lot of information in tabular form for two or more consecutive years. However, the information disclosed one year cannot be compared with previous years due to the changes in measures in subsequent report that companies prepare.

Study proved that the range of the measures used and disclosed varies across editions of the reports, and this is not only a consequence of a modification of the GRI standards.

The statistical analysis allowed us to accept the hypothesis that changes of measures used in CSR reports concern the removal of a measure and the addition of a new measure equally. It may mean that, in order to hide negative information but to keep the same level of disclosure, companies may manipulate the information replacing removed measures with new indicators. This may imply that companies replace previously used indicators with those that present the company in a more favorable light.

This thesis may be supported with results of further analysis that indicate that companies don't explain reasons of changes of measures revealed. It decreases a reliability of the information presented in CSR reports and their usefulness. Moreover, it transpired that there is no real difference in the number of changes made between companies from controversial industries and other branches, so the tendency to avoid negative information may concern all branches.

\section{References}

Barakat, S. R., Isabella, G., \& Boaventura, J. M. G. \& Mazzon, J. A. (2016). The Influence of Corporate Social Responsibility on Employee Satisfaction. Management Decision, 54(9), 2325-2339. https://doi.org/10.1108/MD-052016-0308

Borgers, A., Derwall, J., Koedijk, K., \& Ter Host, J. (2013). Stakeholder Relations and Stock Returns: on Errors in Investors' Expectations and Learning. Journal of Empirical Finance, 22, 159-175. https://doi.org/10.1016/ j.jempfin.2013.04.003

Brammer, S., \& Millington, A. (2008). Does It Pay to Be Different? An Analysis of the Relationship Between Corporate Social and Financial Performance. Strategic Management Journal, 29(12), 1325-1343. https://doi.org/10. $1002 /$ smj.714

Browning, N., Gogo, O., \& Kimmel, M. (2018). Comprehending CSR Messages: Applying the Elaboration Likelihood Model. Corporate Communications: An International Journal, 23 (1), 17-34. https://doi.org/10.1108/CCIJ-07-20170068

Cai, Y., Jo, H., \& Pan, C. (2012). Doing Well While Doing Bad? CSR in Controversial Industry Sectors. Journal of Business Ethics, 108 (4), 467-480. https://doi.org/10.1007/s10551-011-1103-7

Calveras, A., \& Ganuza, J. J. The Role of Public Information in Corporate Social Responsibility. Journal of Economics \& Management Strategy, 25 (4), 990-1017. https://doi.org/10.1111/jems.12156

Campbell, D., Craven, B., \& Shrives, P. (2003). Voluntary Social Reporting in Three FTSE Sectors: a Comment on Perception and Legitimacy. Accounting, Auditing \& Accountability Journal, 16(4), 558-581. https://doi.org/10.1 $108 / 09513570310492308$ 
Chatzoglou, P., Amarantou, V., Chatzoudes, D., \& Aggelidis, V. (2017). Examining the Antecedents and the Effects of CSR Implementation: an Explanatory Study. EuroMed Journal of Business, 12(2), 582-595. https://doi.org/10.1108/EMJB-12-2016-0035

Cheng, M. M., Green, W. J., \& Chi Wa Co J. (2015), The Impact of Strategic Relevance and Assurance of Sustainability Indicators on Investors' Decisions. Auditing: A Journal of Practice \& Theory, 34 (1), 131-162. https://doi.org/10. 2308/ajpt-50738

Cho, Ch. H., Michelon, G., Patten, D. M., \& Roberts, R. W. (2015). CSR disclosure: the more things change...? Accounting, Auditing \& Accountability Journal, 28(1), 14-35. https://doi.org/10.1108/AAAJ-12-2013-1549

Cohen, J., Holder Webb, L., \& Zamora, V. L. (2015). Nonfinancial Information Preferences of Professional Investors. Behavioral Research in Accounting, 27 (2), 127-153. https://doi.org/10.2308/bria-51185

Dagiliene, L., Leitoniene, S., \& Grencikova, A. (2014). Increasing Business Transparency by Corporate Social Reporting: Development and Problems in Lithuania. Inzinerine Ekonomika-Engineering Economics, 25(1), 54-61. https://doi.org/10.5755/j01.ee.25.1.2356

Daszynska-Zygadlo K., Slonski, T., \& Zawadzki, B. (2016). The Market Value of CSR Performance Across Sectors. Inzinerine Ekonomika-Engineering Economics, 27(2), 230-238. https://doi.org/10.5755/j01.ee.27.2.13480

Deegan, C., \& Unerman, J. (2011). Financial accounting theory. Sydney: McGraw-Hill.

Di Giuli, A., \& Kostovetsky, L. (2014). Are Red or Blue Companies More Likely to Go Green? Politics and Corporate Social Responsibility. Journal of Financial Economics, 111 (1), 158-180. https://doi.org/10.1016/j. jfineco.2013.10.002

Dimson, E., Karakas, O., \& Li, X. (2015). Active Ownership. Review of Financial Studies, 28(12), 3225-3268. https://doi.org/10.1093/rfs/hhv044

Douvis, J., Kyriakis, V., Kriemadis, A., \& Vrondou, O. (2015). Corporate Social Responsibility (CSR) Effectiveness in the Greek Professional Sport Context. International Journal of Sport Management Recreation and Tourism, 17(C), 37-45. https://doi.org/10.5199/ijsmart-1791-874X-17c

Du, S. L., Bhattacharya, C. B., \& Sen, S. (2010). Maximizing Business Returns to Corporate Social Responsibility (CSR): The Role of CSR Communication. International Journal of Management Reviews, 12(1), 8-19. https://doi.org/10.111 1/j.1468-2370.2009.00276.x

Eccles, R., Ioannou, I., \& Serafeim, G. (2014). The Impact of Corporate Sustainability on Organizational Processes and Performance. Management Science, 60(11), 2835-2857. https://doi.org/10.1287/mnsc.2014.1984

Einwiller, S., Ruppel, Ch., \& Schnauber, A. (2016). Harmonization and Differences in CSR Reporting of US and German Companies: Analyzing the Role of Global Reporting Standards and Country-Of-Origin. Corporate Communications: An International Journal, 21(2), 230-245. https://doi.org/10.1108/CCIJ-09-2014-0062

Gjolberg, M. (2009). Measuring the Immeasurable? Constructing an Index of CSR Practices and CSR Performance in 20 Countries. Scandinavian Journal of Management, 25(1), 10-22.

Grougiou, V., Dedoulis, E., \& Leventis, S. (2016). Corporate Social Responsibility Reporting and Organizational Stigma: The Case of "Sin" Industries. Journal of Business Research, 69, 905-914. https://doi.org/10.1016 /j.jbusres.2015.06.041

Habek, P., \& Wolniak, R. (2015). Factors Influencing the Development of CSR Reporting Practices: Experts' versus Preparers' Points of View. Inzinerine Ekonomika-Engineering Economics, 26(5), 560-570. https://doi.org/10.57 55/j01.ee.26.5.7690

Hetze, K. (2016). Effects on the (CSR) Reputation: CSR Reporting Discussed in the Light of Signaling and Stakeholder Perception Theories. Corporate Reputation Review, 19(3), 281-296. https://doi.org/10.1057/s41299-016-0002-3

Juscius, V., \& Jonikas, D. (2013). Integration of CSR into Value Creation Chain: Conceptual Framework. Inzinerine Ekonomika-Engineering Economics, 24(1), 63-70. https://doi.org/10.5755/j01.ee.24.1.2016

Khan, M., Serafeim, G., \& Yoon, A. (2015). Corporate Sustainability: First Evidence on Materiality. The Accounting Review, 91(6), 1697-1724. https://doi.org/10.2308/accr-51383

Kuo, L. \& Chen, V. (2013). Is Environmental Disclosure an Effective Strategy on Establishment of Environmental Legitimacy for Organization? Management Decision, 51 (7), 1462-1487. https://doi.org/10.1108/MD-06-2012-0395

Lee, S., \& Park, S. Y. (2010). Financial Impacts of Socially Responsible Activities on Airline Companies. Journal of Hospitality \& Tourism Research, 34(2), 185-203. https://doi.org/10.1177/1096348009349822

Lulewicz-Sas, A. (2014). A New Approach to Evaluation of Socially Responsible Activities. Actual Problems in Economics, 153, 370-380. 
Maignan, I., \& Ralston, D. A. (2002). Corporate Social Responsibility in Europe and The U.S.: Insights from Businesses' Self-Presentations. Journal of International Business Studies, 33(3), 497-514. https://doi.org/10.105 7/palgrave.jibs.8491028

Margolis J. D., \& Walsh J. P. (2001). People and Profits? The Search for a Link Between a Company's Social and Financial Performance. Mahwah, NJ: Lawrence Erlbaum Associates.

Morimoto, R., Ash, J., \& Hope, C. (2005). Corporate Social Responsibility Audit: from Theory to Practice. Journal of Business Ethics, 62(4), 315-325. https://doi.org/10.1007/s10551-005-0274-5

Morioka, S. N., \& Carvalho, M. M. (2016). Measuring Sustainability in Practice: Exploring the Inclusion of Sustainability into Corporate Performance Systems in Brazilian Case Studies. Journal of Cleaner Production, 136, $123-133$. https://doi.org/10.1016/j.jclepro.2016.01.103

O'Donovan, G. (2002). Environmental Disclosures in the Annual Report: Extending The Applicability and Predictive Power of Legitimacy Theory. Accounting, Auditing and Accountability Journal, 16(4), 523-557. https://doi.org/10.1108/09513570210435870

Omran, M. A., \& Ramdhony, D. (2015). Theoretical perspectives on corporate social responsibility disclosure: a critical review. International Journal of Accounting and Financial Reporting, 5(2), 38-55. https://doi.org/10.5 296/ijafr.v5i2.8035

Omran, M. A., \& El-Galfy, A. M. (2014). Theoretical perspectives on corporate disclosure: a critical evaluation and literature survey. Asian Review of Accounting, 22(3), 257-286. https://doi.org/10.1108/ARA-01-2014-0013

Peloza J. (2009). The Challenge of Measuring Financial Impacts from Investments in Corporate Social Performance. Journal of Management, 35(6), 1518-1541. https://doi.org/10.1177/0149206309335188

Peng, J., Sun, J., \& Luo, R. (2015). Corporate Voluntary Carbon Information Disclosure: Evidence from China's Listed Companies. Word Economy, 38 (1), 91-109. https://doi.org/10.1111/twec.12187

Segui-Alcaraz, A. (2012). Development of a Classification of Spanish Credit Institutions Based on the Concept of Stakeholder. Inzinerine Ekonomika-Engineering Economics, 23(5), 442-451.

Sethi, S. P. (1975). Dimensions of Corporate Social Performance. California Management Review, 17 (3), $58-64$. https://doi.org/10.2307/41162149

Theodoulidis, B., Diaz, D., Crotto, F., \& Rancati, E. (2017). Exploring Corporate Social Responsibility and Financial Performance Through Stakeholder Theory in the Tourism Industries. Tourism Management, 62, $173-188$. https://doi.org/10.1016/j.tourman.2017.03.018

Vergner, J. P. (2012). Stigmatized Categories and Public Disapproval of Organizations: a Mixed-Methods Study of the Global Arms Industry, 1996-2007. Academy of Management Journal, 55(5), 1027-1052. https://doi.org/10.5465/amj.2010.0599

Vveinhardt, J., \& Andriukaitiene, R. (2014). Social Responsibility Discourse in Empirical and Theoretical Lithuanian Scientific Studies. Inzinerine Ekonomika-Engineering Economics, 25(5), 578-588. https://doi.org/10.5755/j0 1.ee.25.5.4898

Wang, Y. S., \& Chen, Y. J. (2017). Corporate Social Responsibility and Financial Performance: Event Study Cases. Journal of Economic Interaction and Coordination, 12(2), 193-219. https://doi.org/10.1007/s11403-015-0161-9

Waniak-Michalak H., \& Michalak J. (2016). Disclosure on Corporate and NGO Cooperation in Poland-Coming Out or a Low Profile Approach? Theoretical Journal of Accounting, 88, 163-182.

Waniak-Michalak, H., \& Michalak, J. (2016). Corporate and NGOs' Voluntary Disclosure on Collaboration. Evidence from Poland. Inzinerine Ekonomika-Engineering Economics, 27(1), 98-108. https://doi.org/10.5755/j01.ee.27.1.9338

Virvilaite, R., \& Daubaraite, U. (2011). Corporate Social Responsibility in Forming Corporate Image. Inzinerine Ekonomika-Engineering Economics, 22(5), 534-543. https://doi.org/10.5755/j01.ee.22.5.972

Valackiene, A., \& Miceviciene, D. (2011). Methodological Framework Analysing a Social phenomenon: Stakeholder Orientation Implementing Balanced Corporate Social Responsibility. Inzinerine Ekonomika-Engineering Economics, 22(3), 300-308. https://doi.org/10.5755/j01.ee.22.3.520

The article has been reviewed.

Received in September, 2017; accepted in May, 2018. 